\section{I. 大学の次期大型核融合計画検討の経緯}

大学に括计る核融合研究は，学術害議会のなかに設 けられている核融合部会に打いて時期に応して研究進 展のレビニーと，それに基つく長期的推進方策が審議 され，その答申に対応して進められてきている。最も 新しいものは昭和59年に核融合部会が依頼しだ専門家 によるワーキングタループの作業から始まった。この ワーキンググルーブは核融合研究の分野を 4 つの大き なカテゴリー、すなわち

(1) トカマク,RFP等の内部電流系

(2) ヘリカル系等の外部導体系

(3) ミラー等の開放端系

(4) レーザー,粒子ビーム等の慣性核融合系

に分けて, 各々の現状分析, 重点課題, 今後の推進方策 等を検討した。さらにこの検討結果を基にして，次期 大型計画の必要性, その方式等について討議がなされ， 大学の次期大型核融合計画としてはへリカル系装置に 上る研究を行らこととして答申がまとめられた。

この結果は，学術審議会の審議を経て昭和61年 2 月 に「大学に拈ける今啳の核融合研究について」といら報 告書としてまとめられた。要約は以下の通りである。

(1) 大学に和ける次期大型計画は外部導体系大型 へリカル装置による研究とし, 全国の研究者の 英知を集めて推進する。

（2）新大型計画の推進母体として，岥阜県土岐市 に新たに国立大学共同利用機関を設立すること が望まいい。

(3) その他の研究分野については既存装㞒の活用 （改造增力を含む）等仩り引続き推進する。 同報告書を受けて，文部省はとの具体化方策を椮討
するため昭和 61 年度に「核融合研究を推進するための 調查協力者会議」(主查: 早川幸男現名古屋大学学長, 関連機関の長，学識経䮖者等15名）を組織し，它の下に 「次期大型へリカル装置設計部会」(主查 : 饭吉京都大 学へリオトロン核融合研究センタ一長)を設置し、大型 ヘリカル装置の険討を始めた。設計部会は昭和61年度

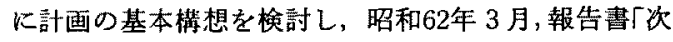
期大型へリカル装直計画の基本構想」(1)を提出しだ。

これを受けて，協力者会議は基本構想についての評 価部会（主查：西川恭治広島大学核融合理論センター 長)を設け，評価·娭討を行うとともに，併せて計画 を推進させる新国立共同利用機関の組織についても 「組織検討部会」(主查：三好昭一筑波大学開放端系核 融合研究センター長)を設け検討を進めた。協力者会 議は「基本構想」について大筋で了承し, 設計部会は 昭和62年度に基本構想をもとに研究実施計画および装 置本体，加熱, 計測機器の概略の設計を行なった。報告 書は近く出版される予定である(2)。

大型計画としていリカ儿系環状磁場薪圈が選択され た理由については，以下のように考支られる。

大学における次期大型計画は, 予想される予算の規 模から考えて，前記 4 つの方式の中から勇断をもって 1つに皎らなければいけない段階である。その際の選 択基準としては，(1)これまでの研究データベースが充 分に活用できる（2)10年先を見て十分に斬新である， (3)多くの研究者が結集できる，等が重要である。 これらの観点から，まず環状磁場閉し还め方式，す なわら内部電流系とへリカル系が選ばれた。次に， University Program of Large Helical Device Experiment: Masami FUJIWARA, Atsuo IrYoshi.

(1988年 4 月19日 受 理) 
リカル系が選ばれた主な理由は，トカマクがすでに 3 大トカマクを中心に世界で広範围に研究されていて， 10年先にインパクトを与え得る計画とすることが難し い。これに対して，へリカル采は我が国のへリオトロ ンEに代表される独自の発展の歴史を有しているこ と，今啳さらに研究を進めることによって世界をりー ドできること，さららに無電流ブラズマの定常実証を行 らことでトカマっと相補的から独創的な研究が期待さ れること，等が棓平価されたと考えられる。

\section{II.ヘリカル系トーラスプラズマ の闒じ込め研究}

核融合炉開発の研究は，核融合反応を起こさせる燃 料によって必要とされるプラズマのパラィータす なわら密度、温度等が異なるが，比較的温度が低くて 達成できる D-T反底を用いた炉の場合でる超高密度 ( $n \geq 10^{28} / \mathrm{cc}$, Cryo or Pycno Nuclear Fusion) 以外の 場合は, 温度 $T>10 \mathrm{keV}$ (1 億息以上), 密度 $n \geq 10^{14} /$ $\mathrm{cc}$ ，閉已込め時間 $\tau_{E} \geq 1 \mathrm{~s}$ 方必要となる。

この条件を満たすへく核融合プラズマの閉じ込めの 研究は行わ机てきた大き分壮て 2 つの方向がある。 1 つはブラスマを櫵成する粒子であるイオン,電子が ローレンッカにより磁力線に巻きつく連動をし，磁場 を横切って逃げないことを利用した磁場閣じ込めであ り，2 番目はレーザー光あるいは高エネルギー粒子ビ ームをェネルギードライハとして然料ターゲットに照 射し，ブラズマが膨脹し始めるまでの短い時間に反応 を起こさせてしまら慣性閉じ込め方式である。

磁昜閉じ込め方式す種々あるが，得られているパラ メ一夕が比較的良いトーラス方式について述べる。プ ラズマ粒子は磁場を横切って逃げないが，磁力線に沿 って自由に運動するので空間的に閣じた磁力線を有す る磁場配位を檴成し，ブラズマを閉じ込めることが必 要になる。このような磁場構造はドーナッ状に閉じた 磁場(トロイダ儿磁場)によって可能であるが、アンペ 一ルの法則でトーラス内側が強く外側が弱い不均一磁 場になり，荷電粒子のドリフト運動が生じ，単純なト ロイダル磁場だけではプラズマ粒子を閉じ込めること はできない。

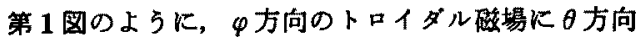
のポロイダル磁を場を重舅させることで，初めてプラズ マ粒子を閉じ込める空間的に閉じた磁場ができるポ ロイダル磁場を生成する方法としてトーラス方向のプ ラズマ電流による方式がトカマクであり，外部に螺旋 型コイル(ヘリカルコイル)を用いるのがヘリカル系ト

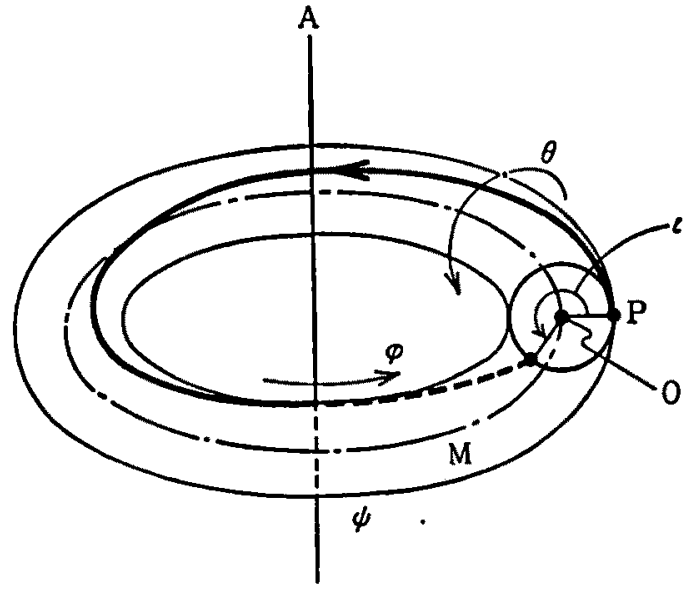

軸A，小半径軸 (磁気軸) $\mathrm{O}$

第 1 图トーラス座標

ーラスである。トカマクはブラズマ粒子間の衝突によ る抵抗，運動量の減衰，すなわら電流の減衰を補ら手 段(電流駆動)が定常運転のために必要であるが，へり カルコイル系はこの必要性がなく原理的に定常運転可 能な磁場構造であるといえる。

外部磁昜コイルのみによりトロイダル状の閉磁気面 を形成しプラズマ閍じ这めを達成しようといら開発 研究は核融合研究の当初から行われてきた。しかし， トカマクがプラズマ電流によって閉じ込め磁場を形成 すると同時に，その電流によって数 $100 \mathrm{~kW}$ というシ ニール加熱を比較的容易に行えるといら利点のために 早い進展を見たことに比ぺ, ヘリカル系はプラズマ生 成・加熱のために大電力加熱用の ECH（電子サイク口 トロン共鳴加熱)源等の開発を待たねばならず,最近に

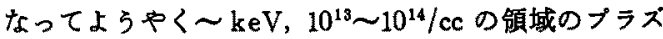
マパラメータを得るよ5になった。第 2 図に, 種々の 核融合開発研究で得られた結果を示す(3)。この図が核 融合研究の進展の度合を示す代表四ですり，この図の 理解，以後の理解の助けとなる意味で $n \tau T$ の意味を简 単に述べる。

例えば，核融合炉の自己点火条件はブラズマのエネ ルギー損失 $W_{P} / \tau_{E}\left(こ こ て ゙, W_{P}\right.$ はブラズマのェネ ルギー)と，核融合反応で生じる $\alpha$ 粒子による自己加 熱入力 $P_{\alpha}$ とが釣り合う条件で决まる。

$$
W_{P} / \tau_{E}=f P_{\alpha}
$$

$こ こ て ， f: \alpha$ 粒子の直接損失，楅射損失その他 の機楼によるエネルギー損失を考 虫した因子

$\alpha$ 䊉子加熱入力は $3 \mathrm{keV}<T 、<30 \mathrm{keV}$ のイオン温 度範囲て 


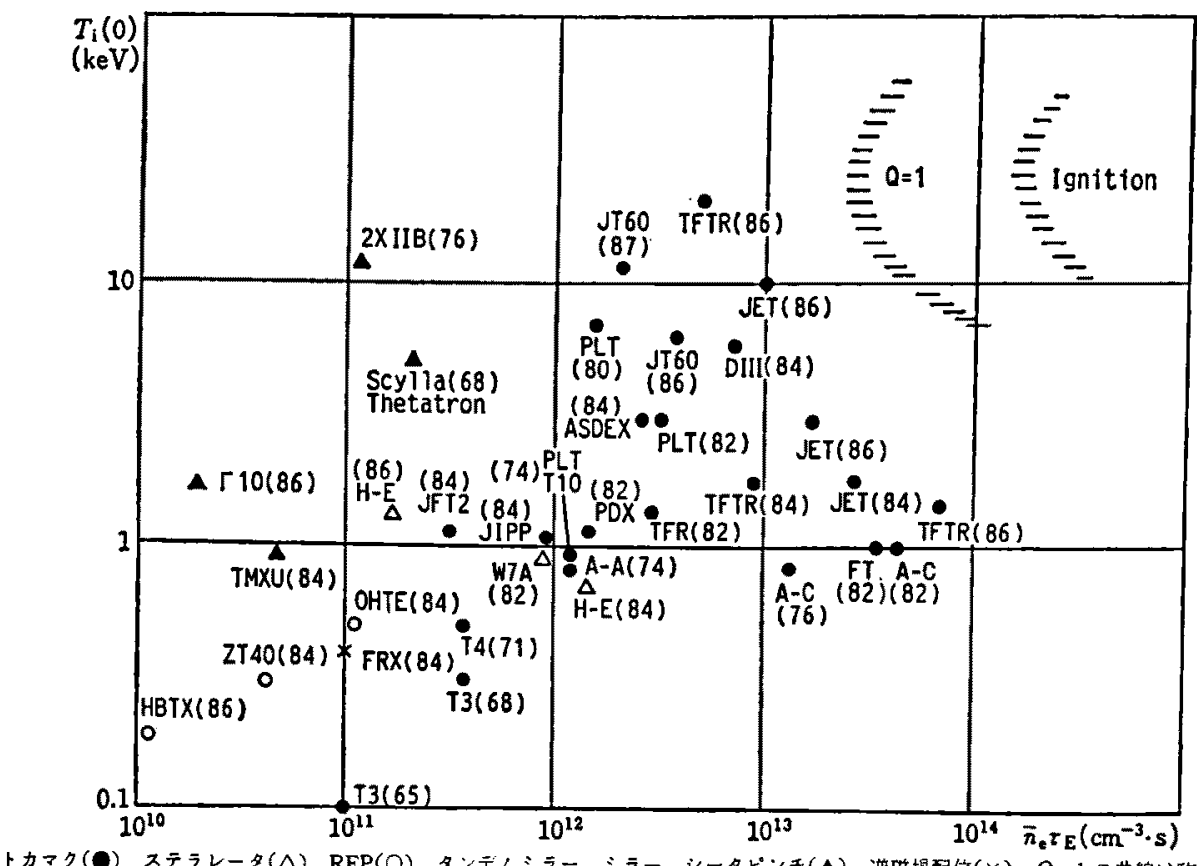

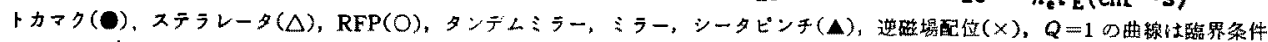
$\left(\bar{n}_{e}:\right.$ 電子密度線平均, $\tau_{E}:$ エネギー閉じ这め時間, $T_{i}:(0):$ 中心におけるイオン温度)

第 2 図 $\bar{n}_{e} \tau_{E}-T_{t}(0)$ ダイフグラムに括ける研究の進展

$$
P_{\alpha}=0.17 \times 10^{-48}<n_{i} T_{i}>^{2} V_{P}
$$

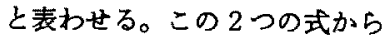

$$
\left\langle n_{20} T_{i}>\tau_{B}=30 f^{-1} \quad\left(10^{20} \mathrm{~m}^{-3} \cdot \mathrm{keV} \cdot \mathrm{s}\right)\right.
$$

が自己点火のための粗い目安になる。<>は体積平 均である。核融合プラズマ閉じ込め研究は, 自己点火 条件の領域を実現することが第一義であるという立場 で進められてきた。一方, 萿術的観点から磁埸核融合 では，実際の磁場コイル設計上困難でない発生磁場強 度から，む51つの要請として，プラズマ压力 $n T$ と 路場の王力の比，ベータ值 $\beta$ に下限がある。すなかり $\beta$ 值が極端に小さい装直は成立しない。仮にて $\tau_{E} \sim(1 \sim$ 2) $\mathrm{s}, f \sim 1$ Łして子

$$
\left\langle n_{i} T_{i}\right\rangle \sim(15 \sim 30) \quad\left(10^{20} \mathrm{~m}^{-3} \cdot \mathrm{keV}\right)
$$

になるので, B〜5 T であれば $<\beta>\sim 5 \sim 10 \%$ が要 求される。大型へリカル装䶊はく $\beta>\sim 5 \%$ 達成を 1 つの目標としている。

\section{III. 次期大型へリカル装連による研究}

\section{1. 基本構想}

今まで述べてきた経緯, ヘリカル系によるプラズ、 閣じ込めの研究の蓄積を踏まえて，大学に括ける核融 合研究の次期計画としての大型へリカル装監による研 究計画を以下のような観点から構想し，その構想を史
現すべく概念設計の検討を行なった。詳細は文献(1)22) にゆずり本章ではその概略を述べる。

まず，ヘリカル系トーラスによるプラズマ閉じ込め 研究の核融合開発における意義は次のように考えられ 索。

核融合炉の呈ましい条件をプラズマ閉じ込めの観点 から考竞ると，炉心プラズマをプラズマのダイナミッ クスとはなるペく無関俰に，外部磁埸コイルで作られ た充分に安定な配位の中にゆっくりと生成していき， 複雑な制御なしに臨界, 自己点火に持ち込んでいくこ とであるが，現実にはトカマクでは，10 MAの電流 が配位維持のためにブラズマ中に流れていること等で 慟々の不安定性が発生してくることなどに大きな課題 がある。ヘリカル系では

(1) プラズマ電流を配位形成に用いずに済むので， ブラズマ中には, プラズマの圧力と磁場の相互 作用から生ずる電流(磁気流体平衡電流 PfirschSchluter 電流やブートストラップ電流）が内在 するだけの状態である。以下に述べられる次期 饻居のプラズマパラメータ範因では，これらの 電流密度はトカマクの電流密度 $\mathrm{MA} / \mathrm{m}^{2}$ に比し て1/10〜1/100であり，ほほ無電流ブラズマ状 態での閉じ込めの研究が可能である。このよう 
な特質を有するへリカル系トーラスがプラズマ 閉し这めから見て核融合师として可能性を有す るかとらかといら点で，炉心ブラズマに外挿し うるパラォータ領域 $\left(n=10^{3} \sim 10^{4} / \mathrm{cc}, T_{i}=5 \sim\right.$ $10 \mathrm{keV})$ で閉し这め，磁気流体的特性，限界 $\beta$ 值 等の研究を行う。むらろんへリカル系トーラス 固有の課題, すなわらへリカル状の磁場の強弱 (ヘリカルリップル)が高温・無衝突プラズマの 閉じ込めを劣化させるかる知れないといら事柄 も当然重要な研究課題である。

(2)今まで造べてきたよらに，外部コイルのみで 閉し込か磁場を形成できることから原理的に定 常運転ができること，さらにその中でも次期装 置として採用するへリオトロン/トルサトロン 配位は 2 本の連続螺旋コイルをトロイダルに沿

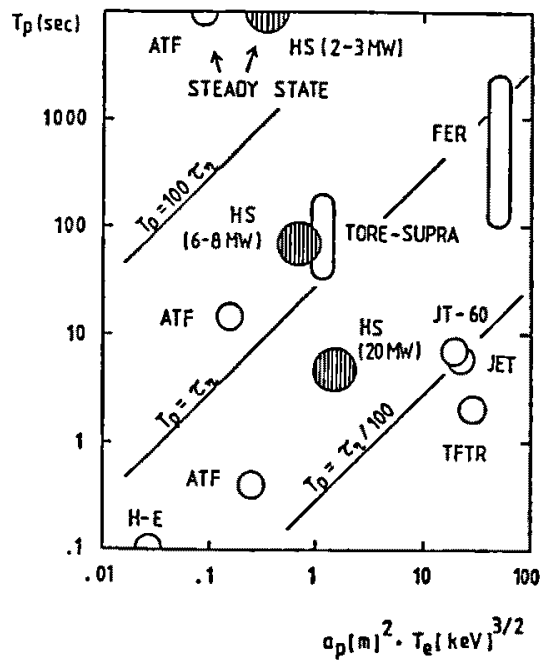

第 3 図(a)磁場拡散時間とプラズマ稳働時間との関保

高温,高密度プラズマの定常保持の研究では 第 4 图に示すよ 5 に,

(a) ガス供給，ペレット入射加熱(密度制御)

(b) 加熱(中性粒子ビーム入射等)による高 エネルギー粒子のエネルギー緩和（加熱 入力制御)

(c) 高温ブラズマ維持(平衡制御)

(d) プラズマー真空容器のガスリサイクリ ング, 不純物輸送

(e) ダイバータ系の粒子制御, 熱除去 の(a)〜(e)までの過程を通じて定常運転のシナリオ の確立を図る。しかし，各段階は時間的にシリ一
って巻いた構造になっており(第 6 図)，それ自 身ダイバータ楧造を有していることを租用し て，高鼬プラズマの定常維持の研究を行らこと ができる。

長時間ないしは定常化の研究は核融合妒（特 に磁場閣じ这め方式)にとって重要な，(然料注

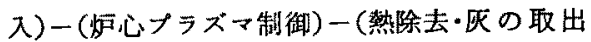
し）のサイクルをシミュレートし，その方法を 確立するための物理的・技術的課題の究明とい ら意味で極めて重要である。時間的スケールの 目安は,長いもので磁場の払散時間, 不純物の蓄 嫧時間, プラズマー壁相互作用の平衡時間等種々 あるが，ここでは 1 つの例として磁場の拡散時 間之運転時間の関係扣よび次期装固での定常実 証をするプラズマパラメータ領城を第 3 図(a), (b)に示す。

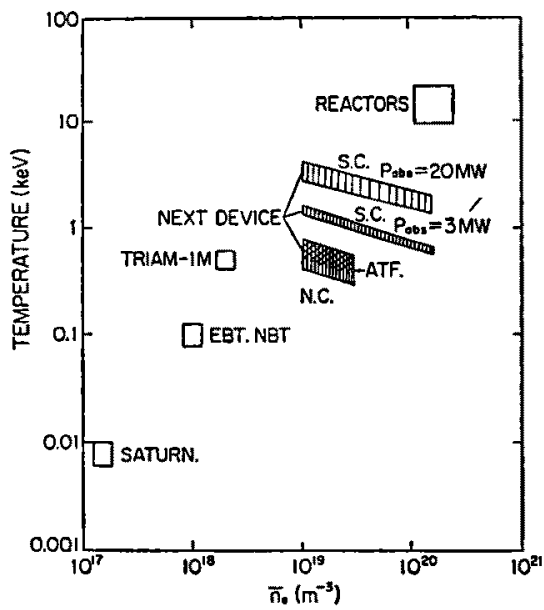

(b)各装䈯の定常運転に拉けるブラズマパラメータ

ズになっておらず，相互に複雑に関連しており， 図中に示される段階の適切な制御の方式を確立す るには充分心長い時間の運転によって初めて可能 で，特にダイバータシステムの付監されている本 計画によって定常核融合帅のプラズマおよび装圈 系を含んだ一連の維持制御の物理・技術の開発が 期待される。

以上に述べた (1)，(2)の項目により，ヘリカル系核融 合妒の可能性を調べるための研究，さらには平均無電 流ブラズマの閉じ込めを通して他の方式，トカマクや RFP の閉じ込めに対しての相補的フブローチ,定常保 持の研究等により，次期計画はトロイダルブラズマの 


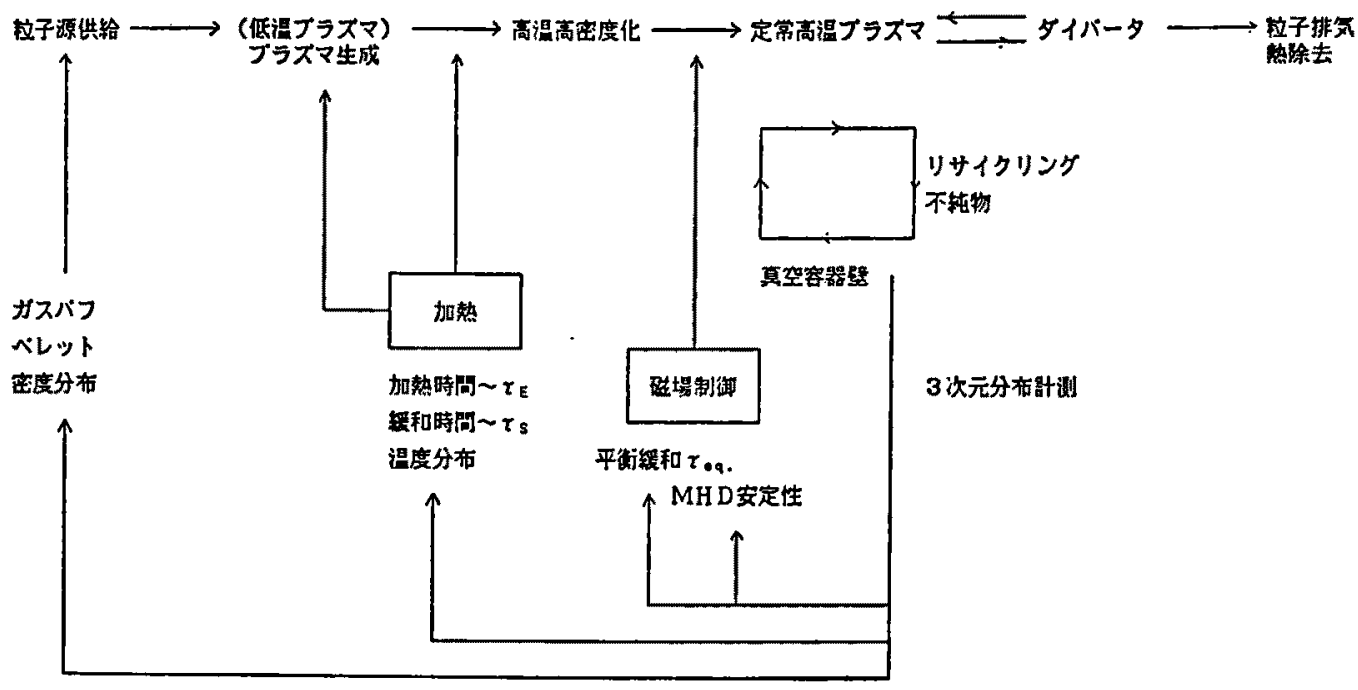

フィードバック制御

第 4 図定常プラズマ維持のシナリオ

粉合的理解を深めるだめに多大の寄与ができる。

次期計画の重点研究課題をまとめると，

(1) 高 $n \tau T$ プラズマを発生し，妒心ブラズマに 外㨉しらる輸送の研究を行ら。

(2) 虭心ブラズマに必要な $\beta$ 值 5\%以上のブラズ マを実現し関連する物理を調べる。

(3) ダイバータ設置, 無電流ブラズマの長パルス 実験を行い，定常運転に必要な基礎資料を得る。

(4) 高エネルギー粒子の振舞いを研究し, 炬心ブ ラズマの粒子のシミュレーション実験を行う。

(5)トカマクとの相補的研究を行う。

これらの課題を実施するため, 目標とするプラズマは，

高 $n \tau T$ 領域 $\bar{T}=3 \sim 4 \mathrm{keV}, \bar{n}=10^{20} \mathrm{~m}^{-3}, B=4 \mathrm{~T}$ $\tau_{R}=0.1 \sim 0.3 \mathrm{~s}$

高 $T_{i}$ 项域 $\quad T_{i}(0) \sim 10 \mathrm{keV}, \bar{n}=2 \times 10^{19} \mathrm{~m}^{-3}$

高 $\beta$ 領域 $\quad \bar{\beta} \geq 5 \%, B=1 \sim 2 \mathrm{~T}$

で，第5図にそのパラメータ領域を示す。

\section{2. 次期大型ヘリカル計画実駼装置}

基本楎想，研究計画の目的を達成するために必要と

考えられる央験装置について述べる。 装直の概略を設計するに当り，

(1) 適正なブラズマ生成,加熱法, 加熱電力で目的 とするパラメータを得るのに必要な装直の寸 法, 磁場强度, 2 本のーリカルコイルのトーラス 方向の巻き数(周期数) $m$ や主半径とコイル小半 径の比のブラズマ特性との関連,フラズ、稼働 および装置の運転時間の検討

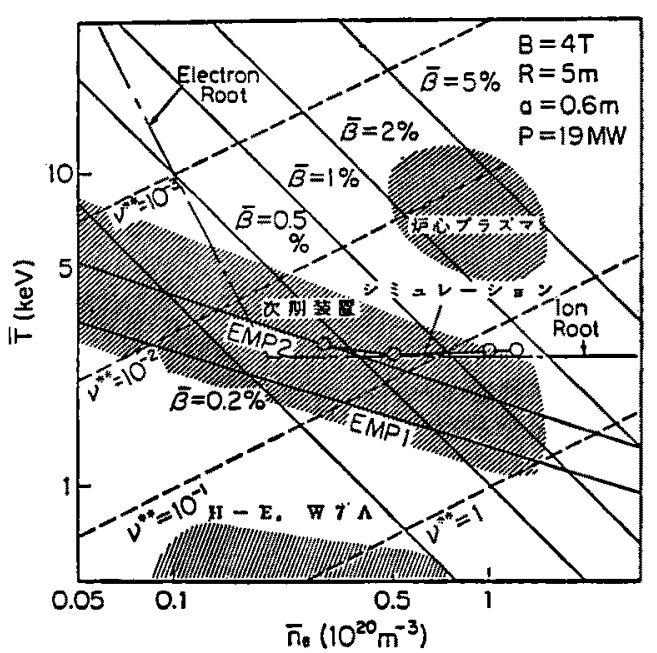

第 5 図次期跡置の目標とするプラズ、領城

(2) 装直本体の設計ではコイルの設計，すなわち 通常の電気銅 (NC) および超伝導線材 (SC) の選 択について技術的可能性, 消費電力, 電源設徣, 冷却系, 加熱, 計測機器の設置し易さ等の面かっ の検討

(3) 加熱機器の検討,初期ブラズマの生成法とし ての ECH(電子サイクロトロン共鳴加熱)，ブラ ズマ高温化のための NBI 加熱(中性粒子入射), ICRF (イオンサイクロトロン加熱) 等について 検討

（4）研究目的達成に必要な計測機器の検討，特に一 
リカル系トーラスプラズマは 3 次元計測が重要で

あることを踏をえての検討

等を行なった。

現段階で設計検討の最も重要なことは，装置本体の コイルとして SC, NC のどちらを用いるかの判断であ った。

（i）物理研究内容の点では，SC 装置の方がょり高 いプラズマパラメータで一連の“無電流”プラズマの 長パルスでの閉じ込め実験が可能，さらにダイバータ による不純物制御を含めた定常実証実験が本格的に可 能であること，(ii）技術的には，SC コイルシステム の製作可能の見通しが得られたこと，NC 装置は $B=$ $4 \mathrm{~T}, R=4 \mathrm{~m}$ では受電容量を越えるだめ小型化の必 要があると，(iii）コスト，製作年限の点では，SC, $\mathrm{NC}$ システム共记全体として大差ないこと，製作年限 はR\&Dを含めて SC の方が $1 \sim 2$ 年長くかかること， 等の検討結果を踏まえて，次期装置としては SC を採 用することとしてより具体的設計を始めている。装置 の設計パラメータ第 1 表をに示す。 SC コイルを用い ての設計に当り考虑すべき点は

(a) 蓄積全磁場エネルギー：2GJ 前後

(b) 導体の線材の選定: $B_{\max } \sim 7.5 \mathrm{~T}$ で $\mathrm{NbTi}$ 系
第 1 表 次期装置の主要パラメータ ( $\mathrm{SC} / \mathrm{NC}$ 装置仕粎)

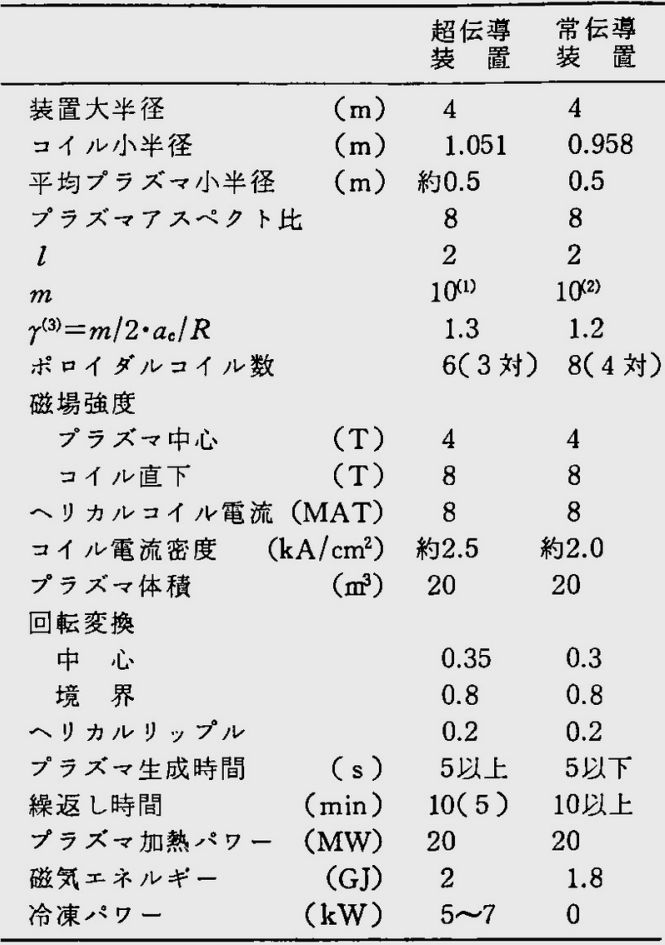

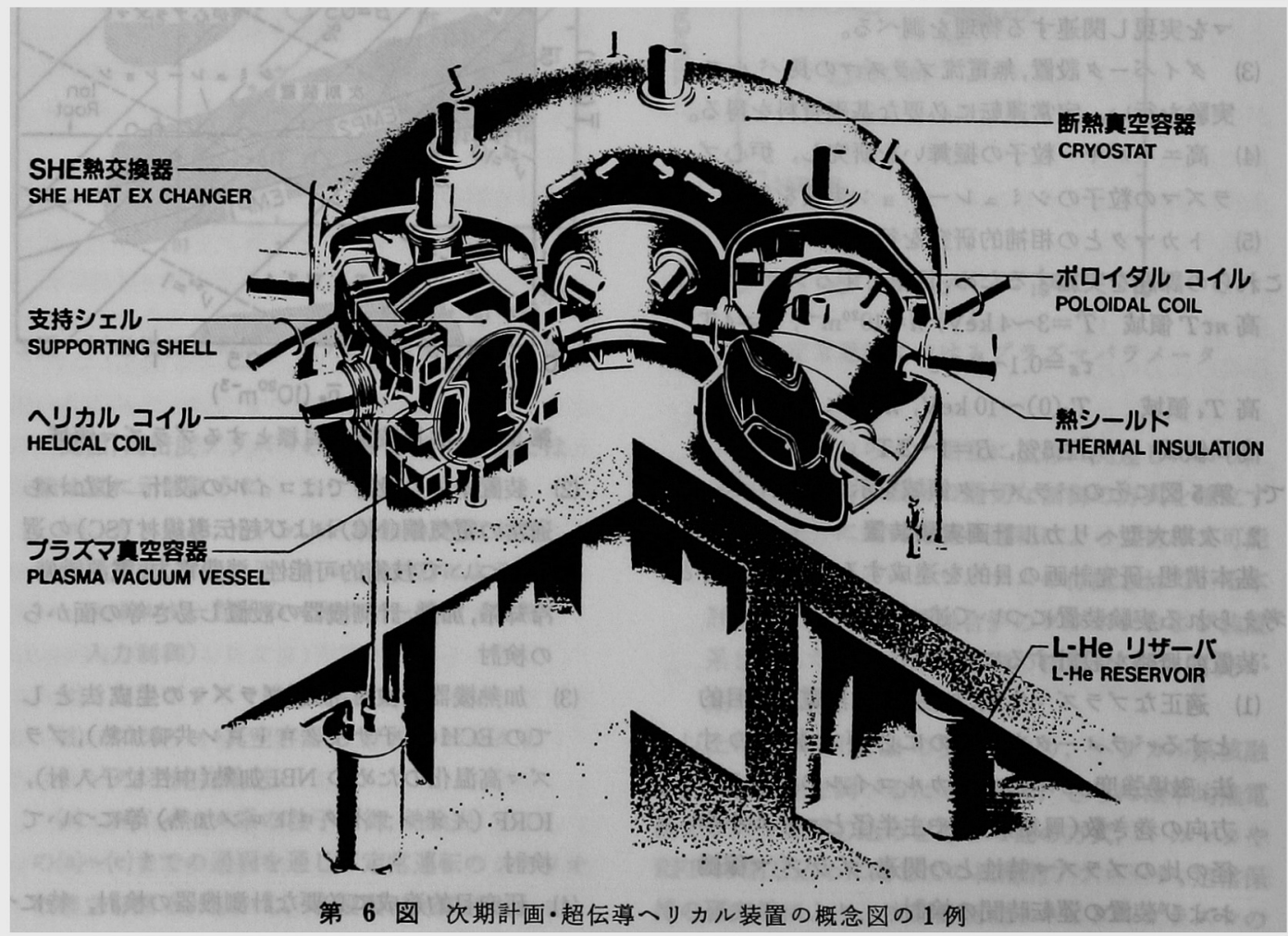


（c）冾却方式之尊体電流: 浸清冷却 $(10 \sim 20 \mathrm{kA})$, 二相流冷却 $(10 \sim 20 \mathrm{kA})$ ，強制冷却 $(40 \mathrm{kA})$

(d) 起磁力 $8 \mathrm{MAT} /$ エイルが必要なので200〜 400 ターンが要求され，コイル導体を途中で接綂す る方式になること(接絩の信頼)，大半径 $R \sim 4 \mathrm{~m}$ のトーラスにへリカルコイルを一体巻きで作る ことから現地巻きになること，等の一連の工程 の配虑

(e) 高精度場 $\left(\delta B / B \sim 10^{-4}\right)$ が望ましいこと

(f) 垂直磁昜コイル等の動的制御，すなるち時間

変動磁場 $(0.15 \mathrm{~T} / \mathrm{s}$ 程度)の影整に対する配庶 等が举げられる。他にる多くの重要項目があるが，こ れらの検討は，設計部会に加えて大学の核融合分野の 専門家, 科研費「エネルギー特別研究」(核融合)第 4 班/
超伝導班，メーカーの技赫者等の協力により進められ ている。本体装固の概念因の1例を第 6 图に示す。

ブラズ、の生成·加熱についても，今までの研究を 通して蓄積された物理・技術の知識を集めて検討され ている。現在考えられている種么の方法を第 2 表に示 す。各手法についてす

(i) $\mathrm{ECH}$ は $100 \mathrm{GHz}$ 以上, 出力 $\mathrm{MW}$ 以上の発 振器中伝送系

(ii) $\mathrm{NBI}$ も高エネルギー $(<100 \mathrm{keV})$ 大電力 $(>10 \mathrm{MW})$

(iil) ICRF 6大電力の伝送系へリカル系に適合 するフンテナ系等の開発

等の多くの新しい物理・技術の開発が必要とされる。

装置本体, 加熱機器, 計測系の整備を行い, 研究計画

第 2 表 プラズマ生成・加熱の方式および概略仕樣

\begin{tabular}{|c|c|c|c|c|}
\hline & 的 & 壮 & 様 & 特徽·意義·必要性 \\
\hline \multicolumn{5}{|c|}{ カテヨ゙リ -1} \\
\hline $\mathrm{ECH}$ & 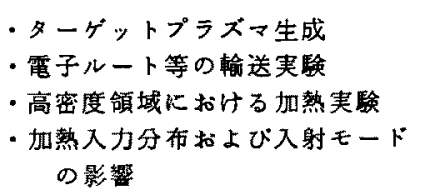 & \multicolumn{2}{|c|}{ 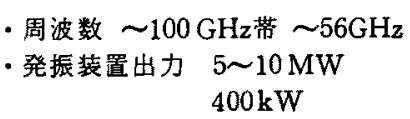 } & $\begin{array}{l}\text { ・ターゲットプラズマ生成・維持・ } \\
\text { 加熱の手段としてはば磼立さ } \\
\text { れている。 } \\
\text { ・伝送系の開発が必要 }\end{array}$ \\
\hline NBI & $\begin{array}{c}\text { ・目標プラズマバラメータ達成 } \\
\text { ・高 } n \tau T \text {, 高 } T_{\mathfrak{n}} \text { 高 } \beta \text { 時の物理実 } \\
\text { 験用プラズマの生成・稚持 }\end{array}$ & 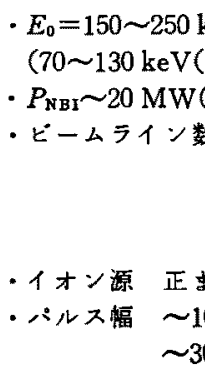 & $\begin{array}{l}\mathrm{eV}\left(\mathrm{D}^{\circ}\right), \\
\left.\left.\mathrm{H}^{\circ}\right)\right) \\
\text { ポート通過) } \\
2 \text { 基 } \\
\left(\mathrm{D}^{\circ} ヒ ゙ ー ム\right) \\
4 \text { 基 } \\
\left(\mathrm{H}^{\circ} ヒ ゙ ー ム\right) \\
\text { たは負イオン源 } \\
\mathrm{s}(20 \mathrm{MW}) \\
\min (4 \sim 5 \mathrm{MW})\end{array}$ & 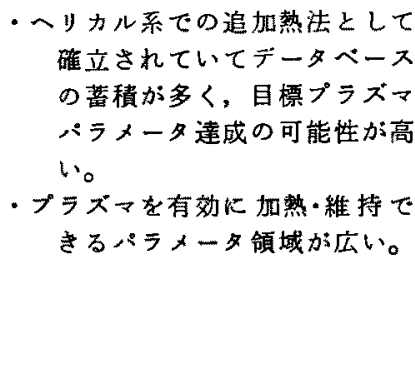 \\
\hline
\end{tabular}

カテン゙

\begin{tabular}{|c|c|c|c|c|}
\hline ICRF & 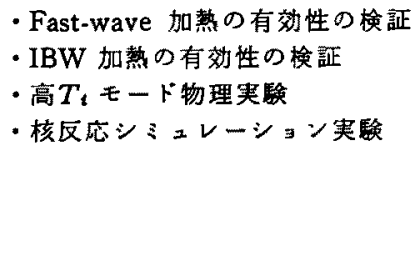 & $\begin{array}{l}\text { - 阔波数 } \\
\text { ・発振出力 } \\
\text { ・ハルス幅 }\end{array}$ & $\begin{array}{l}30 \sim 90 \mathrm{MHz} \text { (可変) } \\
15 \mathrm{MW} \\
\sim 10 \mathrm{~s}(15 \mathrm{MW}) \\
\sim \mathrm{CW}(5 \mathrm{MW})\end{array}$ & 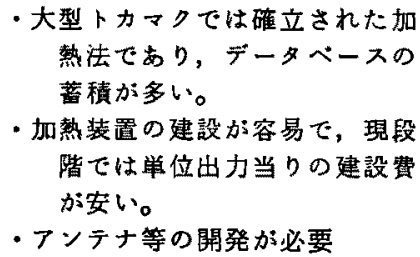 \\
\hline LHCD & ・電流歌動・制御の可能性の検証 & $\begin{array}{l}\text { - 周波数 } \\
\text { - 発振出力 } \\
\text { ・ハルス幅 }\end{array}$ & $\begin{array}{l}3.7 \mathrm{GHz} \\
\sim 5 \mathrm{MW} \\
\sim 100 \mathrm{~s}\end{array}$ & $\begin{array}{c}\text { ・ヘリカル系での波動による電流 } \\
\text { 制御と閉じ込めとの関連 } \\
\text { ・発振装置建設が容易 } \\
\text { ・ランチ+一開発必要 }\end{array}$ \\
\hline $\begin{array}{r}\text { Whistler } \\
\text { wave }\end{array}$ & $\begin{array}{c}\text { ・磁場強度に依存しないブラズマ } \\
\text { 加熱生成 }\end{array}$ & $\begin{array}{l}\text { - 周波数 } \\
\text { ・発振出力 } \\
\text { ・ハルス愊 }\end{array}$ & $\begin{array}{l}\sim 500 \mathrm{MHz} \\
\sim 5 \mathrm{MW} \\
\sim 10 \mathrm{~s}\end{array}$ & $\begin{array}{l}\text { ・磁場強度に依存しない実駼 } \\
\text { ・アンテナ最適化必要 } \\
\text { ・発振装置建設が容易 }\end{array}$ \\
\hline
\end{tabular}

カテゴリー1: 主にプラズスパラメータ達成用, カテゴリー2: 主に物理实験研究用 


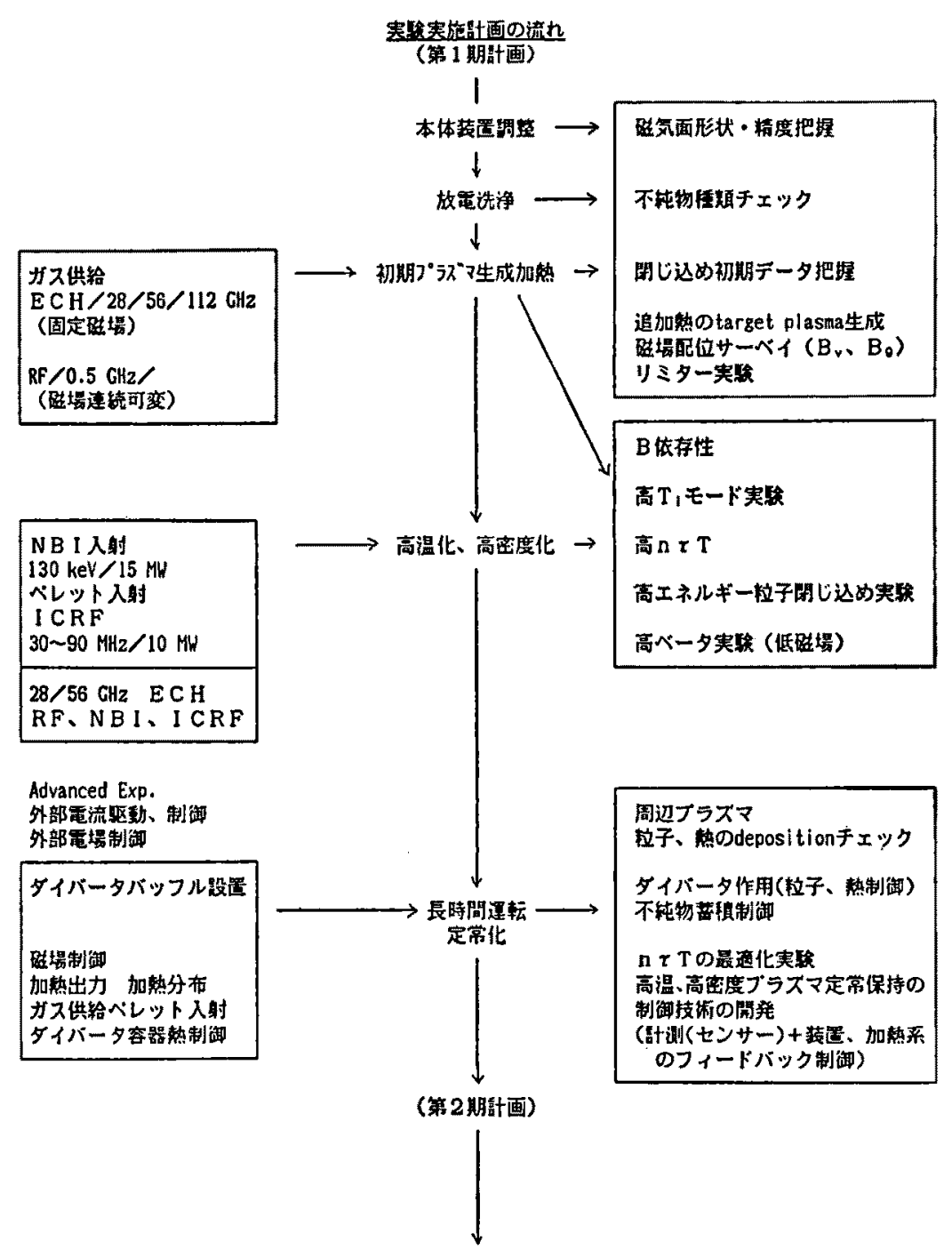

第 7 图実娩実施語画の流れ

としては第 7 図に示されているよらな手順を経て着実 に研究目標を達成していく予定である。

スケシュールとしては，土岐市に斿ける新国立共同 利用機関を設立すべく昭和63年度に創設準備室が動さ

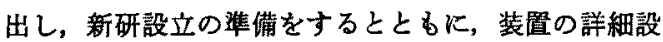
計を進め，昭和69年ないしは70年に装置完成を目指し て装着の製作，加熱・副測の諸機器の慗作を進めてい く。もちろん各分野のR\&Dを踏まえてのことである。 本計画が大学全体の核融合次期計画として関連分野の 研究者の協力により推進されることが望まれる。

終りに，本報は次期大型ヘリカル計画の設計ダー
プの作業報告を同グループに代わって紹介させて頂い たるのであることを继断わりしておきます。設計グル ープ、評洒部会，その他の方々のご協力に感謝いたしま \$。

$$
\text { 一考文献一 }
$$

（1）次期大型へリカル畒置設計ダルーブ：㐸期大型へリカ 儿装置計画の基本楅想 (昭62.3.).

（2）同 上：次期大型へリカル装置計画報告書(第 1 部(研 究計画)，第 2 部 (本体並ひ基本設計)，第 3 部(各分 野別埌告曺))，(昭63.3).

（3）宮本揵郎: “核融合のためのプラズマ物理”。（1987）, 岩波著店. 